\title{
Necrolytic acral erythema: a rare skin disease associated with hepatitis $C$ virus infection*
}

\author{
Luciane Francisca Fernandes Botelho ${ }^{1,2}$ \\ Mauro Yoshiaki Enokihara ${ }^{1}$
}

\author{
Milvia Maria Simões e Silva Enokihara ${ }^{1}$
}

Abstract: Necrolytic acral erythema is a rare skin disease associated with hepatitis $\mathrm{C}$ virus infection. We report a case of a 31-year-old woman with hepatitis $\mathrm{C}$ virus infection and decreased zinc serum level. Physical examination revealed scaly, lichenified plaques, well-demarcated with an erythematous peripheral rim located on the lower limbs. After blood transfusion and oral zinc supplementation the patient presented an improvement of lesions.

Keywords: Hepatitis C, chronic; Necrolytic migratory erythema; Zinc deficiency

\section{INTRODUCTION}

Necrolytic acral erythema is a rare skin disease associated with hepatitis $C$ virus infection. ${ }^{1}$ It is characterized, in the initial phases, by erythematous or violaceous papules, bullae and erosions. In the late phase, there is onset of well-delimited plaques with erythema on their outer rim, lichenification, secondary hyperpigmentation and fine desquamation on the surface. ${ }^{2}$ Topical treatments are ineffective. Some studies show improvement of lesions after treatment for hepatitis $C$ virus infection and zinc supplementation. ${ }^{3}$

\section{CASE REPORT}

Female patient, 31 years old, reported on her first consultation lesions on her legs for the previous four months, initially pruritic and later painful. She associated the onset of lesions to insect bite. She reported history of atopy and drug-induced hepatitis due to use of contraceptive.

At the dermatological examination, she presented lichenified plaques, well-delimited, with erythema on outer rim and desquamation on the surface, located on the legs and on third left toe (Figure 1). The histological examination showed excoriated psoriasiform dermatitis. A topical corticosteroid was prescribed, and the

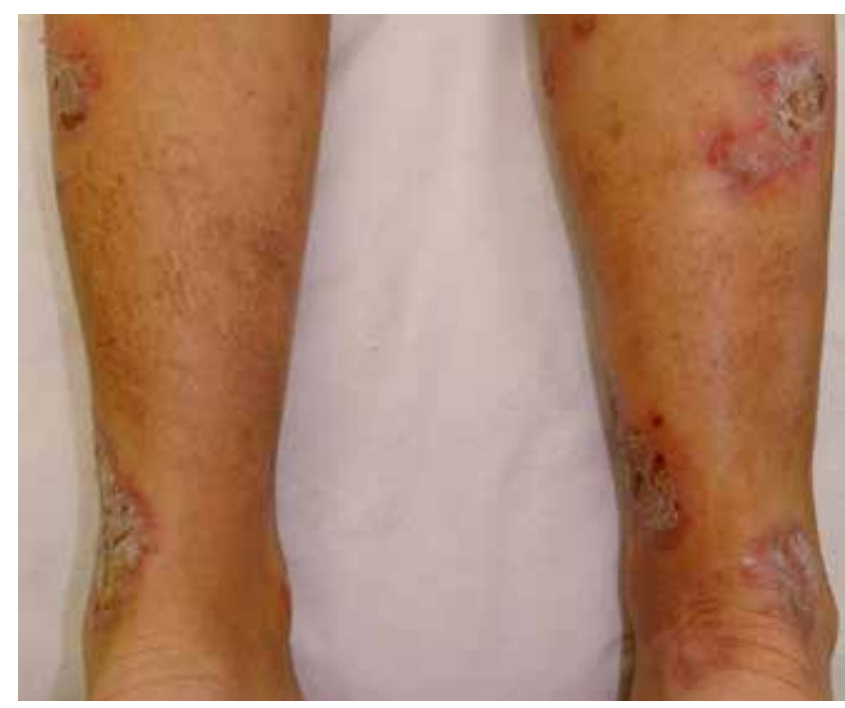

FIGURE 1: Lichenified plaques, well-delimited, with erythema on their outer rims and desquamation in the surface, located on the legs 
patient had periods of partial improvement during one year. After one year and half of follow-up, the patient was hospitalized with digestive hemorrhage, and was diagnosed with hepatitis $C$ virus infection. She received blood transfusion during hospitalization, and the cutaneous lesions regressed. Considering the diagnosis of infection by hepatitis $C$ virus and clinical aspect of lesions, the possibility of diagnosing it as necrolytic acral erythema was raised. The patient underwent histological examination again, which showed acanthosis, psoriasiform hyperplasia, papillomatosis with hyperkeratosis and superficial perivascular lymphocytic infiltrate (Figure 2). Dosage of zinc serum level was at $0.26 \mathrm{mg} / \mathrm{ml}(0.50-1.10)$. After confirmation of necrolytic acral erythema diagnosis, the patient received zinc oral supplementation at a dose of $220 \mathrm{mg}$ twice a day, without relapses of cutaneous lesions. (Figure 3).

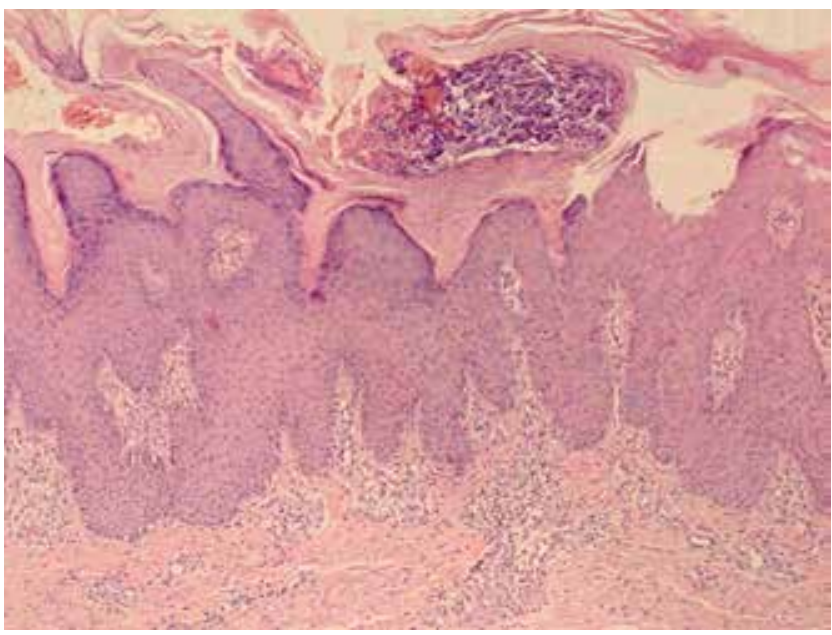

FIGURE 2: Histology - Acanthosis, psoriasiform hyperplasia, papillomatosis with hyperkeratosis and superficial perivascular lymphocytic infiltrate (HE, 100x)

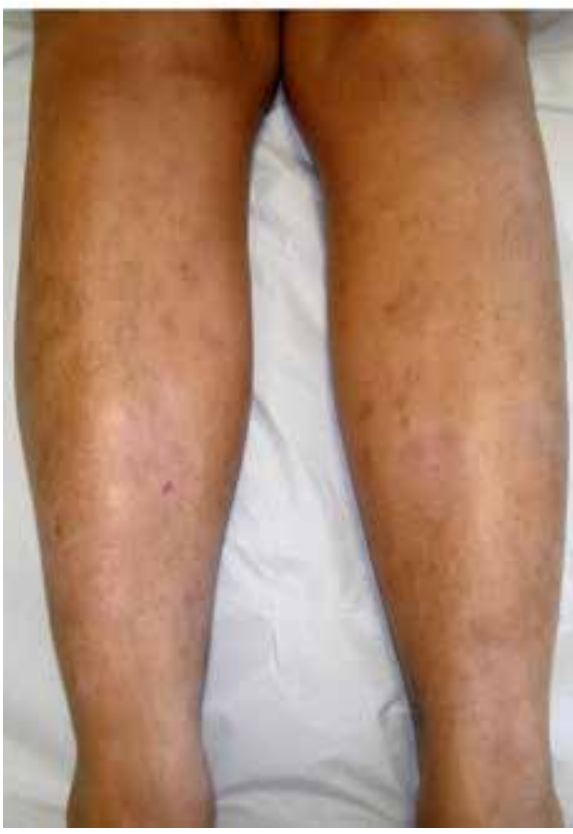

Figure 3:

Patient without lesions after zinc supplementation

\section{DISCUSSION}

Chronic hepatitis $\mathrm{C}$ virus infection affects approximately 170 millions of people worldwide. Hepatic cirrhosis and hepatic carcinoma are the most severe complications related to chronic infection, however associated extra-hepatic manifestations may occur, such as cryoglobulinemia, porphyria cutanea tarda, lichen planus and necrolytic acral erythema. ${ }^{4}$

Necrolytic acral erythema was described in 1996 in seven Egyptian patients as a specific cutaneous manifestation of infection by hepatitis $\mathrm{C}$ virus. ${ }^{5}$ A study recently published showed a prevalence of $1.7 \%$ for necrolytic acral erythema among patients with infections caused by hepatitis $C$ virus. ${ }^{1}$ The most common location of lesions is the back of feet and toes, but they can also affect the surface of the Achilles tendon, the malleolus, legs and knees. Associated symptoms are pruritus, pain, burning and dysesthesia. ${ }^{6}$ In the case reported, the patient presented lesions with compatible morphology, location and histology and also reported pain at the sites of lesions.

The histological findings are not pathognomonic, therefore it is necessary clinical suspicion for the diagnosis. Among the histological changes, we can observe, in the initial phases, acanthosis, spongiosis and superficial perivascular infiltrate. In the late phase, the lesions present psoriasiform hyperplasia and intense papillomatosis with parakeratosis. It is possible to observe, in some cases, subcorneal pustule and necrotic keratinocytes in chronic lesions. ${ }^{7}$

Patient received blood transfusion and the lesions regressed, probably due to zinc present in the transfused blood. Later, oral therapy with zinc was prescribed, and patient remained without lesions, even though she was not treating the infection by hepatitis $C$ virus. The pathogenesis of necrolytic acral erythema is unknown, nevertheless it is believed that the metabolic change caused by hepatitis $C$ virus may cause an alteration in the regulation of zinc. Moneib et al published a study which showed serum levels of zinc, lesional and perilesional levels all diminished in patients with necrolytic acral erythema. ${ }^{8}$ Although some studies show improvement after zinc supplementation, other authors do not report any gain from this treatment. Thus, there are controversies regarding the association between necrolytic acral erythema and zinc deficiency. ${ }^{9}$

Necrolytic acral erythema may mimic other dermatoses, such as psoriasis, pellagra, acrodermatitis enteropathica and necrolytic migratory erythema. ${ }^{6}$ Thus, when these diagnoses are suspected in patients with infection by the hepatitis $C$ virus, the dermatologist must be alert regarding the possibility of this specific cutaneous manifestation linked to such viral infection.] 


\section{REFERENCES}

1. Raphael BA, Dorey-Stein ZL, Lott J, Amorosa V, Lo Re V 3rd, Kovarik C. Low prevalence of necrolytic acral erythema in patients with chronic hepatitis $C$ virus infection. J Am Acad Dermatol. 2012;67:962-8.

2. Yost JM, Boyd KP, Patel RR, Ramachandran S, Franks AG Jr.. Necrolytic acral erythema. Dermatol Online J. 2013;19:20709.

3. Bentley D, Andea A, Holzer A, Elewski B. Lack of classic histology should not prevent diagnosis of necrolytic acral erythema. J Am Acad Dermatol. 2009;60:504-7.

4. Ko HM, Hernandez-Prera JC, Zhu H, Dikman SH, Sidhu HK, Ward SC, et al. Morphologic features of extrahepatic manifestations of hepatitis $\mathrm{C}$ virus infection. Clin Dev Immunol. 2012;2012:740138.

5. el Darouti M, Abu el Ela M. Necrolytic acral erythema: a cutaneous marker of viral hepatitis C. Int J Dermatol. 1996;35:252-6.

6. Abdallah MA, Ghozzi MY, Monib HA, Hafez AM, Hiatt KM, Smoller BR, et al. Necrolytic acral erythema: a cutaneous sign of hepatitis $C$ virus infection. J Am Acad Dermatol. 2005;53:247-51.

7. Abdallah MA, Ghozzi MY, Monib HA, Hafez AM, Hiatt KM, Smoller BR, et al. Histological study of necrolytic acral erythema. J Ark Med Soc. 2004;100:354-5.

8. Moneib HA, Salem SA, Darwish MM. Evaluation of zinc level in skin of patients with necrolytic acral erythema. Br J Dermatol. 2010;163:476-80.

9. Iyengar S, Chang S, Ho B, Fung MA, Konia TH, Prakash N, et al. Necrolytic acral erythema masquerading as cellulitis. Dermatol Online J. 2014;20. pii:

\author{
MAILING ADDRESS: \\ Luciane Francisca Fernandes Botelho \\ Rua Borges Lagoa, 508 \\ 04038-000 - São Paulo - SP \\ Brazil \\ E-mail: lucianebotelho@hotmail.com
}

How to cite this article: Botelho LFF, Enokihara MMSS, Enokihara MY. Necrolytic acral erythema: a rare skin disease associated with hepatitis C virus infection. An Bras Dermatol. 2016;91(5):649-51. 